RESEARCH ARTICLE

\title{
Motivating Factors for Women to Become Agripreneurs
}

\section{Sree Madhumitha $\mathbf{G}^{1^{*}}$ and Karthikeyan $\mathbf{C}^{2}$}

${ }^{* 1}$ Department of Agricultural Extension and Communication, Agricultural College and Research Institute, Killikulam - 628252

${ }^{2}$ Department of Social Sciences, Agricultural College and Research Institute, Killikulam- 628252

\begin{abstract}
Women entrepreneurship has tremendous potential in accelerating the economic growth of our nation. Not only for economic growth but also for social upliftment and women empowerment, women entrepreneurship becomes inevitable. To increase the proportion of women entrepreneurs, they need to be motivated. This paper highlights the motivating factors for women agripreneurs. The study was carried out in Namakkal district of Tamil Nadu during December 2019. The top five agro-based industries of two taluks, namely Namakkal and Paramathi Velur, were selected. All the 60 women agripreneurs of these industries in the two taluks were selected as respondents. The secondary data were collected from the District Industries Centre (DIC), and the primary data were collected through a structured pre-tested interview schedule. Using the Henry Garret ranking technique, the motivational factors were ranked. The study results revealed that family support was the prime and most vitalmotivating factor for women entrepreneurs for their successful entrepreneurial behavior.
\end{abstract}

Received : 03 ${ }^{\text {rd }}$ August, 2020

Revised : $28^{\text {th }}$ August, 2020

Accepted : $16^{\text {th }}$ September, 2020

\section{Keywords: Women entrepreneurs; Agripreneurs; Motivational factors; Women development; Motivation.}

\section{INTRODUCTION}

Agriculture in India was the primary and largest economic sector. It contributes $18 \%$ of income to the GDP and employs more than $50 \%$ of the country's population (Madhusudhan, 2015). In Tamil Nadu, the total number of establishments was 8.05 million, in which 2.76 million were engaged in agricultural activities (34.3\%). One of the best potential alternatives to find employment for the rural population was entrepreneurship in rural industries.More than two-thirds of the population depends on agriculture for employment. During independence, agriculture contributed more than half of the national income, along with more than $70 \%$ of the people were dependent on agriculture (Pandey, 2013).

Women were considered as the better half of the society as they constituted half of the country's total population. But, they were not treated as the better half. Social customs and practices imprisoned them for years. In both inside and outside of the four walls of the house, women were not provided with equal rights and opportunities. After independence, women were forced or in need to turned out to be an entrepreneur for their livelihood. There were 26.61 Lakh female-owned enterprises out of 361.76 Lakh enterprises in India, which employ 120 Lakh female employees out of 805 Lakh employees (Annual Report, 2014-15). In addition to this, in India, 13.5\% of enterprises were female-run establishments. Among these, Tamil Nadu possessed the most significant number of women-owned enterprises (1.08 Million), followed by Kerala (0.91 Million) and Andhra Pradesh (0.56 Million) (Sixth Economic Census, 2016). Kadharlal and Premevathy (2008) defined women entrepreneurs as 'a women or group of women who initiate, organize, and run business enterprises. In a developing nation like India, there exists a need for women entrepreneurs to exploit the uncharted dimension of business undertakings. Shah (2012) commented that, for the acceleration of our nation's economic growth, there is a need for an increased supply of women entrepreneurs. Supporting this, the role of women entrepreneurs have become significant for the economic development of our nation (Garg \& Agarwal, 2017)

Women entrepreneurs were primarily motivated by their internal characteristics like desire of independence and recognition, to run an enterprise, and to overcome the challenges (Raman et al., 2008; Ismail et al., 2012; Ramadani et al., 2013). The studies of Beltran and Ursa (2006) and Luehrsen (2010) identified that the desire to be their own boss was one reason for women to start-up their own enterprise. The primarymotivators of women entrepreneurs were financial success (Carter N.M. et al., 2003); self-realization (Badulescu, 2010); desire for self-determination, career challenge, and

$107|7-9| 333$ 
self-fulfillment (Buttner \& Moore, 1997), (Mansor, 2005). For women entrepreneurs, the strongest motivators to initiate their own business venture were self-achievement, and independence meanwhile the weakest motivators were job satisfaction, economic necessity and security Beltran and Ursa (2006). Studies by Wang et al.,(2004), Mcclelland E. et al., (2005), reported that push and pull factors encouraged women to be entrepreneurs. The push factors were the hardships, and the pull factors were the opportunities.

Several research studies in India and abroad confirm the following different motivational factors for women to become entrepreneurs. They were family members as a major source of inspiration (Padaki, 1994); financial sufficiency (Narmatha et al., (2002); Sivacharan et al., (2015)). Meanwhile, Geetha and Ranjani (2017) identified seven factors that highly motivate women entrepreneurs; they were Generation of Income, Economic Independence, Interest, Self-Dependent, Family Encouragement, Social status, and Self prestige. Simultaneously, Justo et al., (2006) and Badulescu (2010) indicated that motivation among men and women doesn't vary to start a business and added that women's need were always unique in business and they were in contrast to men's need. Whereas, Madhumitha and Karthikeyan (2020) reported family support as the key factor which promotes women entrepreneurship. Nevertheless, Alam et al., (2012, observed that the motivations of women in the entrepreneurial process was not known.

In India, women were equally populated as males. But, they were not on par with men. Based on a survey done by Female Entrepreneurship Index (2015) among 77 countries, the Female Entrepreneurship Index revealed that India ranked 70. It depicted that there was an insufficient and unfriendly environment for women entrepreneurship development and growth in India. Despite the unfavorable situation prevailing in India, Tamil Nadu possessed a greater number of women entrepreneurs. To bridge the gap of unknown to known, this study was intended to bringthe motivating factors of women involved in entrepreneurship. Among different sectors, agriculture was the prime contributor to National Economy. Hence women entrepreneurs of agriculture sector were selected. The objective of the study is to find out the motivating factors of women.

\section{MATERIAL AND METHODS}

The study was conducted in the Namakkal district of Tamil Nadu, as it secured the second rank in the highest female work participation rate (42.8\%) (Census, 2011). In Namakkal, there were four taluks, namely Namakkal (52 enterprises), ParamathiVelur (30 enterprises), Tiruchengode (23 enterprises) and Rasipuram (12 enterprises). Out of four taluks, the two major taluks which possessed the highest number of agro-based enterprises were selected (i.e) Namakkal and ParamathiVelur. The list of agro-based enterprises that existed in Namakkal were collected from District Industries Centre (DIC), Namakkal. With reference to the different agro-based enterprises in Namakkal, the top five enterprises which were operated by a maximum number of women entrepreneurs were selected. The selected enterprises were grain milling products, food products like papad, grinding of spices, dairy product, vegetable oil and starch product. All the 60 women agripreneurs in the two taluks under the five types of agro-based industries were selected as respondents. A list of 10 motivational factors were identified for the study, with the help of available literatures, previous studies, opinion survey from the sample respondents and experts's opinion in the field of agricultural extension and agribusiness. The primary data were collected from the selected sample of women agripreneurs through a personal interview with the help of a structured schedule during December 2019.

\section{RESULTS AND DISCUSSION}

The preference of motivational factor among women agripreneurs were studied during the interview and analyzed through Henry Garret Ranking technique and the results are presented in Table1.

Table 1 Preference and ranking of motivational factor by women agripreneurs $(n=60)$

\begin{tabular}{|c|c|c|c|c|c|c|c|c|c|c|}
\hline \multirow[t]{2}{*}{ Motivational Factor } & \multicolumn{10}{|c|}{ Rank Given by Women Agripreneurs } \\
\hline & $1^{\text {st }}$ & $2^{\text {nd }}$ & $3^{\text {rd }}$ & $4^{\text {th }}$ & $5^{\text {th }}$ & $6^{\text {th }}$ & $7^{\text {th }}$ & $8^{\text {th }}$ & $9^{\text {th }}$ & $10^{\text {th }}$ \\
\hline Financial support & 2 & 9 & 2 & 2 & 10 & 2 & 2 & 6 & 2 & 2 \\
\hline Social recognition & 2 & 4 & 8 & 15 & 6 & 4 & 2 & 5 & 0 & 0 \\
\hline Self-identity & 17 & 4 & 6 & 8 & 0 & 4 & 7 & 0 & 0 & 0 \\
\hline Government policies & 0 & 0 & 0 & 2 & 4 & 5 & 0 & 0 & 4 & 15 \\
\hline Innovative thinking & 0 & 4 & 6 & 4 & 6 & 4 & 2 & 9 & 0 & 2 \\
\hline Family support & 0 & 9 & 23 & 10 & 6 & 4 & 6 & 0 & 0 & 0 \\
\hline Need for additional family income & 17 & 8 & 6 & 4 & 2 & 2 & 2 & 2 & 13 & 0 \\
\hline High demand for products & 2 & 10 & 4 & 4 & 9 & 10 & 9 & 2 & 0 & 0 \\
\hline To continue family business & 8 & 2 & 0 & 3 & 9 & 2 & 2 & 4 & 0 & 0 \\
\hline Overcome unemployment & 12 & 10 & 5 & 2 & 0 & 9 & 6 & 6 & 2 & 0 \\
\hline
\end{tabular}




\section{Calculation of the Garret score using Percent Position}

The Garret score was found by using the per cent value in garret ranking conversion table. The per cent value can be calculated using per cent position formula.

The formula for calculating per cent position was

Percent position $=100\left(R_{i j}-0.5\right) / N_{i}$

$\mathrm{R}_{\mathrm{ij}}=$ Rank given for the $\mathrm{i}^{\text {th }}$ variable by the $\mathrm{j}^{\text {th }}$ respondent

$\mathrm{Nj}=$ number of variables ranked by the $\mathrm{j}^{\text {th }}$ respondent

Table 2. Per cent Value and Garret Score

\begin{tabular}{lrr}
\hline $100\left(R_{i j}-0.5\right) / N_{j}$ & Per cent value & Garret Score \\
\hline $100(1-0.5) / 10$ & 5 & 82 \\
$100(2-0.5) / 10$ & 15 & 70 \\
$100(3-0.5) / 10$ & 25 & 63 \\
$100(4-0.5) / 10$ & 35 & 58 \\
$100(5-0.5) / 10$ & 45 & 52 \\
$100(6-0.5) / 10$ & 55 & 48 \\
$100(7-0.5) / 10$ & 65 & 42 \\
$100(8-0.5) / 10$ & 75 & 36 \\
$100(9-0.5) / 10$ & 85 & 29 \\
$100(10-0.5) / 10$ & 95 & 18 \\
\hline
\end{tabular}

The calculated per cent value was converted into garret score by multiplying the garret table (Table 1) and garret score of each motivational factor (Table 2).

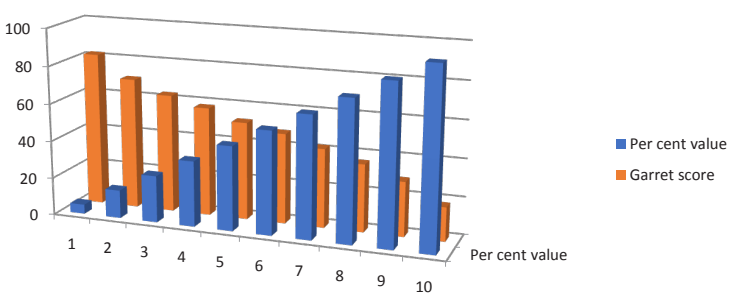

Figure 1. Percent value and Garret Score of motivational factors

The result is provided in the Table 2 and Figure 1.

\section{Calculation of Garret Value and Ranking}

Finally, by adding all the scores of each motivational factor given by the women agripreneurs yielded the total garret score. The calculation of Garret score and ranking of the motivational factor are shown in the Table 3 and Figure 2.

Table 3 revealed that all the motivational factors ranked by the women agripreneurs of Namakkal district. The women agripreneurs had given the rank based on their experience. The ranks were obtained through Henry Garret Ranking technique method. Family support was the first and the most important motivating factor, followed by the need for additional family income, overcome unemployment, self-identity, high demand for products, social recognition, financial support, innovative thinking, to continue family business, Government policies as $2^{\text {td }}, 3^{\text {rd }}, 4^{\text {th }}, 5^{\text {th }}, 6^{\text {th }}, 7^{\text {th }}, 8^{\text {th }}, 9^{\text {th }}$ and $10^{\text {th }}$ ranks respectively.

Since the family is the basic unit of society and also being the inevitable part of a women's life; support from family members becomes necessary to achieve great success. Hence, most of the women agripreneurs consider their family support as the most essential driving factor which motivates them to establish and run the enterprise successfully. Further, in this scientific world, increasing price of goods and living styles leads to additional need for income. Consequently, increased level of education, awareness, and creativity made women seek a job to disclose their self-identity andget rid of unemployment. Whereas, the good quality of their products at a reasonable price leads to a high demand for products in the market and in turn makes their venture profitable. Simultaneously, the social recognition earned by them because of their enterprise, timely financial support for establishing and running the enterprise, innovative ideas, and products to sustain the competitive nature, to continue the family business in a traditional way motivates them to run the enterprise.

Table 3. Calculation of Garret Score and ranking of the motivational factor

\begin{tabular}{|c|c|c|c|c|c|c|c|c|c|c|c|c|c|}
\hline Motivational Factor & $1^{\text {st }}$ & $2^{\text {nd }}$ & $3^{\text {rd }}$ & $4^{\text {th }}$ & $5^{\text {th }}$ & $6^{\text {th }}$ & $7^{\text {th }}$ & $8^{\text {th }}$ & $9^{\text {th }}$ & $10^{\text {th }}$ & Total & $\%$ & Rank \\
\hline Financial support & 164 & 630 & 126 & 116 & 520 & 96 & 84 & 216 & 58 & 36 & 2046 & 20.46 & 7 \\
\hline Social recognition & 164 & 280 & 504 & 870 & 312 & 192 & 84 & 180 & 0 & 0 & 2586 & 25.86 & 6 \\
\hline Self-identity & 1394 & 280 & 378 & 464 & 0 & 192 & 234 & 0 & 0 & 0 & 2942 & 29.42 & 4 \\
\hline Government policies & 0 & 0 & 0 & 116 & 208 & 240 & 0 & 0 & 116 & 270 & 950 & 9.5 & 10 \\
\hline Innovative thinking & 0 & 280 & 378 & 232 & 312 & 192 & 84 & 324 & 0 & 36 & 1838 & 18.38 & 9 \\
\hline Family support & 0 & 630 & 1449 & 580 & 312 & 192 & 252 & 0 & 0 & 0 & 3415 & 34.15 & 1 \\
\hline $\begin{array}{l}\text { Need for additional family } \\
\text { income }\end{array}$ & 1394 & 560 & 378 & 232 & 104 & 96 & 84 & 72 & 377 & 0 & 3297 & 32.97 & 2 \\
\hline High demand for products & 164 & 700 & 252 & 232 & 468 & 480 & 378 & 72 & 0 & 0 & 2746 & 27.46 & 5 \\
\hline To continue family business & 656 & 140 & 0 & 174 & 468 & 96 & 84 & 144 & 0 & 0 & 1762 & 17.62 & 8 \\
\hline Overcome unemployment & 984 & 700 & 315 & 116 & 0 & 432 & 252 & 216 & 58 & 0 & 3073 & 30.73 & 3 \\
\hline
\end{tabular}


Eventually, lack of awareness and long time taken by the Government officials to process the application seems to be the least motivating factor.

The findings of the study are in line with the studies of Padaki (1994), Geetha and Rajani (2017) and Madhumitha and Karthikeyan (2020) reported that family support was the key factor for the entrepreneurial success of women entrepreneurship. Similar studies by Narmatha et al., (2002), Shivacharan et al., (2015) and Geetha and Rajani (2017) were in consonance with the finding that financial support was one of the motivating factors for women entrepreneurs. Self-identity and social recognition were also regarded as ahighly motivating factor (Geetha \& Rajani, 2017).

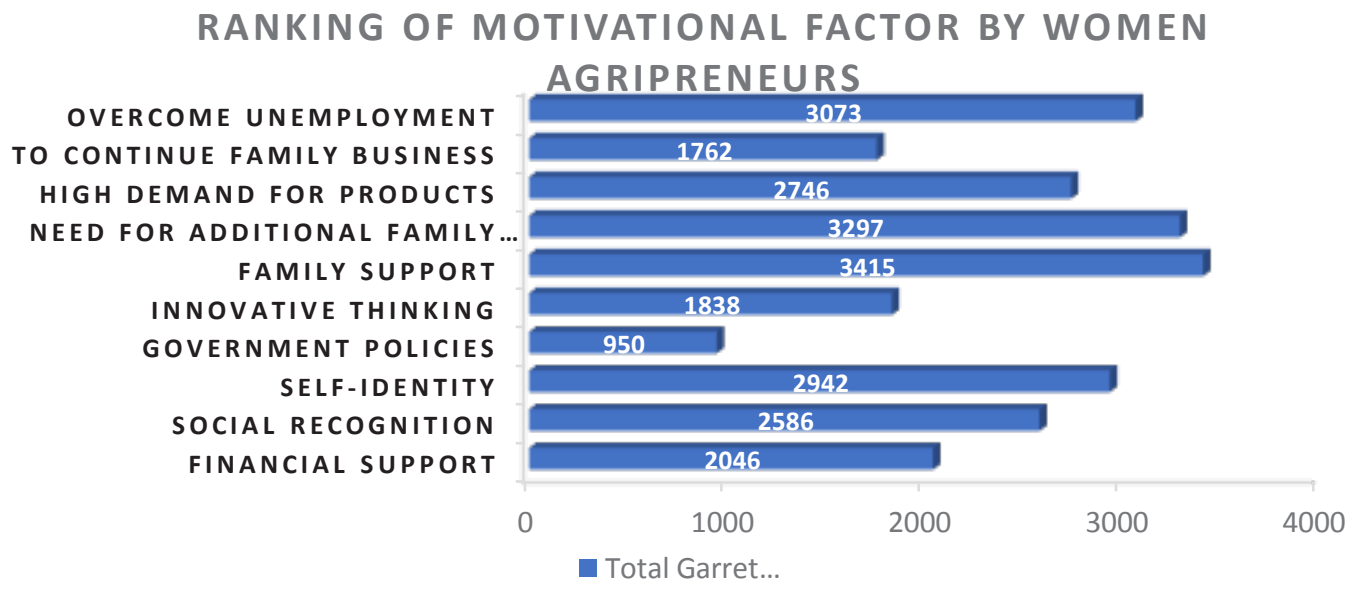

Figure 2. Ranking of Motivational factors by Women Agripreneurs

The innovative thinking of women entrepreneurs was one of the important motivating factor that makes them unique and to be successful in their enterprise (Madhumitha \& Karthikeyan, 2020). Findings of Jaiswal (2004) revealed that the need for additional family income, self-identity, financial support, independence were considered as the motivating factors.

\section{CONCLUSION}

The motivation was the prime factor that urges us to do something and make our routine life. It may be from external sources or internal sources. For instance, family support was the foremost essentialand most vitalmotivating factor for women entrepreneurs. Similarly, need for additional income, desire for independence, need to be one's own boss, need for achievement, financial support, need for achievement, to continue family business, innovative thinking and overcome unemployment were some of the strongest motivating factors that motivated women to start up their own business venture. Women entrepreneurs had tremendous potential and there was an increased number of women entrepreneurs nowadays. Their potential can be tapped by moulding their entrepreneurial traits and skills using an appropriate training programme. Understanding the motivating factors of women entrepreneurs, will enable the policy makers, government officials, District Industries Centre (DIC), MSME; to formulate policy for enhancing their motivational factor and to provide subsidy for the welfare of women agripreneur.

\section{Funding and Acknowledgment}

There are no funding sources for this study.

\section{Originality and plagiarism}

I solely declare that this research article is originally written by the author. The article has not been submitted elsewhere for publication or consideration.

\section{Consent for publication}

All the authors agreed to publish the content.

\section{Competing interests}

There were no conflict of interest in the publication of this content

\section{Data availability}

All the data of this manuscript are included in the MS. No separate external data source is required. If anything is required from the MS, certainly, this will be extended by communicating with the corresponding author through corresponding official mail; angelinmadhumitha@gmail.com.

\section{REFERENCES}

Alam, S. S., Senik, Z. C., \& Jani, F. M. (2012). An exploratory study of women entrepreneurs in malaysia: Motivation and problems. Journal of Management Research, 4(4): 282-297. 
Annual Report, M. (2014-15). Msme.Ministry of micro, small and medium enterprises. Government of India.

Badulescu, A. (2010). Entrepreneurial motivations: Are women driven by different motivators than men?(ithe literature). Annals of Faculty of Economics, 1(1): 234-241.

Beltran, M.-a. E., \& Ursa, Y. (2006). Benchmarking analysis on women entrepreneurs and workers in ict industry. WISE-Benchmarking Analysis Report. WISE project, co-financed by the Leonardo da VinciProgramme of the European Commission.

Carter, N. M., Gartner, W. B., Shaver, K. G., \& Gatewood, E. J. (2003). The career reasons of nascent entrepreneurs. Journal of business venturing, 18(1): 13-39.

Female Entrepreneurship Index, R. (2015). Retrieved from https://thegedi.org/female-entrepreneurshipindex-2015-report/

Garg, S., \& Agarwal, P. (2017). Problems and prospects of woman entrepreneurship. IOSR Journal of Business and Management, 19(01): 55-60.

Geetha, K., \& Rajani, N. (2017). Factors motivating women to become entrepreneurs in chittoor district. International Journal of Home Science, 3: 752-755.

Ismail, H.C., Shamsudin, F. M., \& Chowdhury, M. S. (2012). An exploratory study of motivational factors on women entrepreneurship venturing in malaysia. Business and Economic Research, 2(1): 1-13

Jaiswal, N. (2004). What motivated women to opt for entrepreneurial career: A study Paper presented at the National seminar on Women Entrepreneurship - A Need for Training and Curriculum Development Development of Home Science Extension and Communication, Faculty of Home Science, M. S. University, Vadodara.

Justo, R., de Castro, J. O., Coduras, A., \& Cruz, C. (2006). Entrepreneurs' perceptions of success: Examining differences across gender and family status. Instituto de Empresa Business School, Forthcoming.

Kadharlal, A., \&Premevathy, N. (2008). Government initiatives for women entrepreneurial development in tamilnadu: Kurukshetra.

Luehrsen, A.E. (2010). A historical view of the development and growth of women-owned businesses in the united states and the motivation behind the growth.
Madhumitha, G. S., \& Karthikeyan, C. (2020). Case study on a successful women entrepreneur in banana halwa production. International Journal of Development Extension, 10(2): 9-12.

Madhusudhan, L. (2015). Agriculture role on indian economy. Bus Econ J., 6(4): 1.

Mansor, N. (2005). Woman in business: Determinants for venturing in malaysianssmes. Studia Universitatis Babes Bolyai-Negotia, 50(2): 41-55.

McClelland, E., Swail, J., Bell, J., \& Ibbotson, P. (2005). Following the pathway of female entrepreneurs. International Journal of Entrepreneurial Behavior \& Research.

Narmatha, N., Krishnaraj, R., \&Safiullah, A. M. (2002). Entrepreneurial behavior of livestock farm women. Indian Journal of Extension Education, 13(4): 3431-3438.

Pandey, G. (2013). Agripreneurship education and development: Need of the day. Asian Resonance, 2(4): 155-157.

Ramadani, V., Gc+rguri, S., Dana, L. C. o.-P., \&TaE!aminova, T. (2013). Women entrepreneurs in the republic of macedonia: Waiting for directions. International Journal of Entrepreneurship and Small Business, 19(1): 95-121.

Raman, K., Anantharaman, R. N., \&Jayasingam, S. (2008). Motivational factors affecting entrepreneurial decision: A comparison between malaysian women entrepreneurs and women non entrepreneurs. Communications of the IBIMA, 2(12): 85-89.

Shivacharan, G., Rani, V. S., \& Reddy, K. M. M. (2015). Entrepreneurial behavior of rural young agri-entrepreneurs and relationship between entrepreneurial behavior and profile characters. Res. Jr. of Agril. Sci., 6(5): 1089-1091.

Sixth Economic Census, M. (2016). All india report of sixth economic census. Retrieved from https:// msme.gov.in/sites/default/files/All\%20India\%20 Report\%20of\%20Sixth\%20Economic\%20Census. $\underline{\mathrm{pdf}}$

Wang, Y., Watkins, D., Harris, N., \& Spicer, K. (2004). The relationship between succession issues and business performance: Evidence from uk family smes. International Journal of Entrepreneurial Behaviour and Research, 10(1-2): 59-84. 